University of Rhode Island

DigitalCommons@URI

Open Access Master's Theses

1981

\title{
Coventry: A Guide to Future Growth Through Environmental Suitability and Land-Use Regulations
}

Richard T. Chew

University of Rhode Island

Follow this and additional works at: https://digitalcommons.uri.edu/theses

\section{Recommended Citation}

Chew, Richard T., "Coventry: A Guide to Future Growth Through Environmental Suitability and Land-Use Regulations" (1981). Open Access Master's Theses. Paper 712.

https://digitalcommons.uri.edu/theses/712

This Thesis is brought to you for free and open access by DigitalCommons@URI. It has been accepted for inclusion in Open Access Master's Theses by an authorized administrator of DigitalCommons@URI. For more information, please contact digitalcommons-group@uri.edu. 
COVENTRY: A GUIDE TO

FUTURE GROWTH THROUGH ENVIRONMENTAL

SUITABILITY AND LAND-USE REGULATIONS

BY

RICHARD T. CHEW

\begin{abstract}
A RESEARCH PROJECT SUBMITTED
IN PARTIAL FULFILLMENT OF THE

REQUIREMENTS FOR THE DEGREE

OF MASTER OF COMMUNITY PLANNING
\end{abstract}

UNIVERSITY OF RHODE ISLAND

1981 


\section{MASTER OF COMMUNITY PLANNING \\ RESEARCH PROJECT \\ OF \\ RICHARD T. CHEW}

APPROVED:
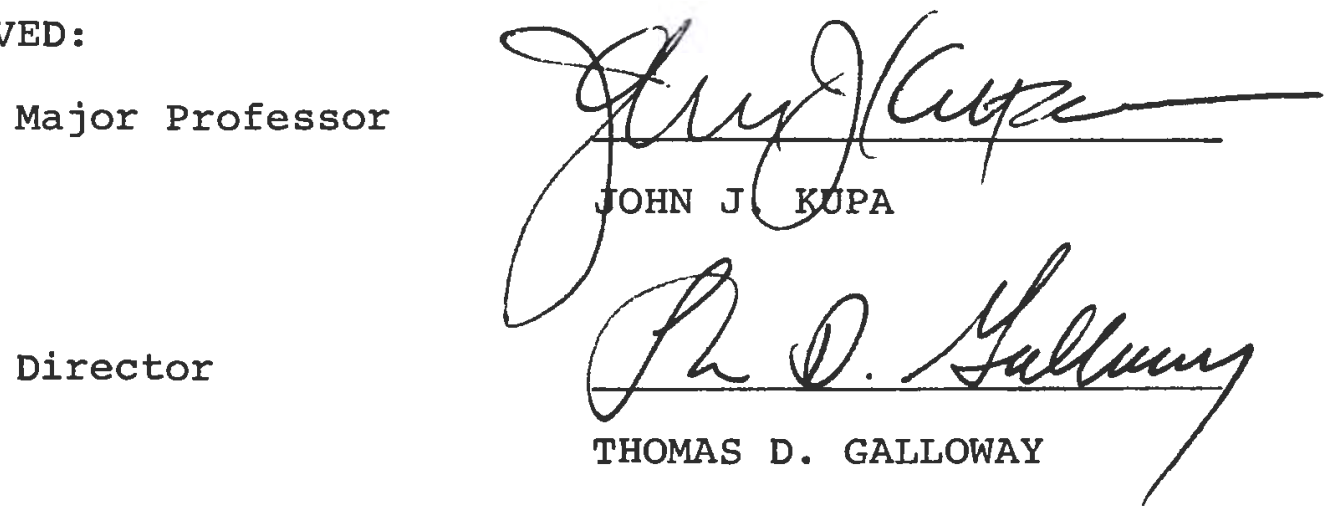


\section{ACKNOWLEDGEMENTS}

I'd like to gratefully acknowledge several people whose help and support have played a vital role in my graduate education. First and foremost, my eternal love and thanks to my parents, who I owe everthing to. I extend my special thanks to Dr. Kupa, whose encouragement and enthusiasm has been an inspiration to me. I'd also like to thank Dr. Galloway, who, despite his responsibilities, has always been most generous with his time. Also, my graditude to Tom Deller for his help on this project. I'd also like to extend my thanks to Eileen Cook and Carol Desalvo for their help and assistance over the past two years. Finally, my love and thanks to Lisa for her constant support and belief in me. 
DEDICATION

This project is dedicated to the "guys" and Patty, whose friendship has made these two years a most REWARDING experience. 
TABLE OF CONTENTS

Page

FORWARD . . . . . . . . . . . . . . $i$, $i i$

INTRODUCTION . . . . . . . . . . . . . . 1

CHAPTER I GROWTH MANAGEMENT ISSUES . . . . . 4

CHAPTER II ENVIRONMENTAL SUITABILITY . . . . 18

CHAPTER III GROWTH MANAGEMENT AND COVENTRY . . 31

CONCLUSION . . . . . . . . . . . . 45

FOOTNOTES ................ 46

APPENDIX A . . . . . . . . . . 47

APPENDIX B............... 51

BIBLIOGRAPHY . . . . . . . . . . 53

THIS REPORT IS COMPLEMENTED BY A SERIES

OF OVERLAY MAPS THAT DETERMINE AREAS OF

ENVIRONMENTAL SUITABILITY IN THE TOWN OF

COVENTRY . 


\section{FORWARD}

The objectives of this project are twofold: 1) increase awareness in the Town of Coventry of the need for local policies that address the issue of growth, and 2) assist the town in formulating policies that will accomodate future growth with the least impact. This report does not advocate a no growth policy, rather it recognizes the need to channel future growth in an orderly and efficient manner.

It is hoped that this report will be published and circulated to various officials and residents of Coventry in hopes of generating a greater awareness and understanding of the issues involved in growth managenent. For this reason, the material in this report is fairly general and nontechnical.

The introduction briefly reviews the issue of growth in Coventry. Chaper I attempts to provide a general overview of current growth management issues on the local level. Chapter II reviews the principle characteristics of environmentally sensative areas and methods for their development. Chapter III focuses on specific growth management strategies relevant to the Town of Coventry.

A series of mylar overlay maps determining environmentally suitable areas supplement this report. These maps include: surface water and wetlands, topography, land use and vegetation, grounwater, soils, ecological diversity, total constraints, and proposed zoning. These maps are designed to be 
used as imputs into the land-use decision-making process for guiding future growth in Coventry through environmental suitability. 


\section{INTRODUCTION}

Coventry is the largest town in the state with 62.25 square miles of land. Coventry is unique; while central and western parts of the town remain largely rural in character, eastern Coventry is one of the most rapidly growing areas in the State. Although approximately $80 \%$ of Coventry remains undeveloped, the town's population has increased $173 \%$ since 1950 (Table I).

\section{Table I}

Town of Coventry

Population Trends and Projections

$$
\text { 1900-1990 }
$$

\begin{tabular}{lll} 
Year Population & $\begin{array}{l}\text { Numerical } \\
\text { Change }\end{array}$ & $\begin{array}{l}\text { Percent } \\
\text { Increases }\end{array}$ \\
\hline
\end{tabular}

\begin{tabular}{lccc}
1900 & 5,279 & & \\
\cline { 3 - 4 } 1910 & 5,848 & 569 & 10.8 \\
1920 & 5,670 & -178 & -3.0 \\
1930 & 6,430 & 760 & 13.4 \\
1940 & 6,998 & 568 & 8.8 \\
1950 & 9,869 & 2,871 & 41.0 \\
1960 & 15,432 & 5,563 & 56.4 \\
1970 & 22,947 & 4,145 & 48.7 \\
1980 & 27,065 & 4,118 & 17.9 \\
1990 & 30,100 & 3,035 & 11.0 \\
Sources: & $\begin{array}{l}\text { U.S. Census } 1900-1980 \\
\text { Rhode Island Statewide Planning } \\
\text { Population Projections April } 1979 .\end{array}$
\end{tabular}


This increase in population over the past thirty years has resulted in a tremendous increase of municipal services, especially schools, * lowered environmental quality, and threatens the rural character of the town. Although Rhode Island Statewide Planning's population projections (Table I) for Coventry predict a moderation in population growth over the next decade (11.0\%), development pressures will continue to grow along with its subsequent impacts. With so much land available for development, Coventry is highly susceptible to wasteful, sprawl development patterns. Also, Statewide population forecasts could be very misleading. Employment opportunities from the recently announced Digital Plant, to be located on the Coventry-West Greenwich line, could result in a tremendous in-migration to the area that Statewide Plannings population projections do not currently take into account.

* In the decade 1960-1970, school enrollment increased from 2,837 to 6,056 , an increase of 135\%. (Coventry Comprehensive Community Plan 1973).

While it is difficult to accurately predict the amount of growth that will occur in Coventry, the real issue is not the amount of growth that will occur, but rather, Coventry's inability to effectively plan for future development. Although much of Coventry remains a rural town in character, it is faced with many of the problems of a rapidly urbanized area. It is the town's reluctance to accept the fact that more regulatory controls and planning expertise are needed, 
that, more than any other single-factor, leaves Coventry highly susceptible to impacts from future growth and development.

It is essential that Coventry officials and residents develop a greater understanding of the issues and options available in controlling growth if the town is to be successful in minimizing impacts from future growth and development. The following chapter reviews current issues and methods for controlling growth on the local level. 


\section{GROWTH MANAGEMENT ISSUES}

\section{INTRODUCTION}

Until recently, most communities viewed growth as a fairly natural and desirable occurrence. Local planners and decision-makers often actively encouraged population and economic growth in their communities. Recently though, there has been a significant change in attitudes. Though many communities still favor expansion, many no longer actively promote development. Some communities even discourage growth through various policy instruments and planning techniques.

This chapter attempts to provide the reader with a general framework for coping with growth on the local level. Growth policies, planning techniques, and legal considerations involved in developing growth management policies will be summarized below.

\section{DEVELOPING GROWTH MANAGEMENT POLICIES}

Every community already has the necessary components to develop growth management policies: public opinions, zoning and subdivision procedures, master plans, building permits, tax rates, capital improvement programs, sewer and water policies, etc. These are all policy instruments that help shape the quantity and quality of growth. Unfortunately, most local governments have not effectively mobilized these elements into a coordinated growth management program.

"Adoption of a growth policy has generally taken two 
forms: either as a separate policy statement, or as part of the comprehensive or master plan." 1 "When initiating a growth management program, it is essential to provide guidance in the form of general goals and objectives for the benefit of the local decision-makers. These goals and objectives should address major policy issues, such as the provision of public facilities and services, environmental protection, housing, employment, transportation, property values, financial planning, and management." 2

The growth management process attempts to influence the primary characteristics of growth: location, type, rate, and amount. Growth policies will likely be formulated around some or all of these factors.

\section{Location}

A policy aimed at managing the location of growth can attempt to restrict areas where development will be permitted and/or use incentives to encourage development in certain areas. While the two objectives differ in terms of the methods used, they both attempt to achieve the same thing.

A community may decide to influence location for a variety of reasons. Among the objectives include: maximum utilization of existing public services, preservation of open space and natural resources, encourage energy efficiency through compact development, or protecting existing land uses such as agricultural or residential areas. 
Type

A local policy designed to manage the type of growth involves special efforts aimed at limiting or encouraging certain land use categories to be provided in the future. "Although the policy may deal only with a general type of land use, in practice the typical approach is to concentrate on the subcategories (Multi-family etc.) of land use." 3

By constraining high density growth the community may be attempting to limit service demand, or attempting to preserve the character of the community.

\section{Rate}

"A policy aimed at managing the rate of growth in an area could be implemented by influencing the number of dwelling units constructed, by limiting the acreage developed or subdivided, or by combining indirect policies that minimize employment opportunities, reduce housing densities, or increase the cost of housing." 4 A growth rate policy assumes that varied types of growth will occur in an area and attempts to deal with the timing of that growth.

There are numerous reasons for developing policies affecting growth rate. The objective most often cited is the attempt to achieve consistency between plans and programs within the community in order that development will occur at approximately the same rate that services become available to accomodate the increased demand. 
Amount

A growth policy affecting the amount of growth in a community will attempt to set a maximum on the total number of people that can be accommodated within that area. Although this is not a commonly used tactic, some places have attempted to set a ceiling on the number of people living within the planning area by placing a numerical limit on the number of dwelling units that can be constructed. Most communities though, attempt to influence amount indirectly by using a combination of standard planning and zoning techniques.

\section{GROWTH MANAGEMENT TECHNIQUES}

A brief description of various qrowth management techniques available to local officials is summarized below.

\section{Public Acquisition}

Government has the greatest capability of managing land when it is publicly owned. Public acquisition techniques include: fee simple acquisition, land banking, compensable regulation, and less than fee simple acquisition.

1) Fee simple acquisition: This technique is employed when full use of the property by the public is required. It provides the public with the greatest flexibility in using the site, but it is the most costly form of public acquisition.

2) Land banking: This technique is used where urban expansion is likely to occur. Land banking serves to minimize urban sprawl and provide for public uses. 
"Through the actual ownership of land, a land bank offers many advantages over more traditional planning devices. It is intended to help promote sounder planning practices by giving public officials a more direct interest in the property and its regulation." 5

3) Compensable regulation: Compensable regulation is the technique of combining compensation with constitutionally acceptable police power regulation. By granting compensation to owners who property was "taken", the public would be permitted greater regulatory flexibility while assuring the equitable treatment of property owners. The idea of compensable regulation is not new, but actual use is rare.

4) Less than fee simple acquisition: Easements may either allow the landowner certain uses for the land or prevent him from using it in certain ways. There are numerous advantages to acquiring easements to the land rather than purchasing the entire fee. "Land encumbered by an easement remains with the landowner. The expense of maintaining the land also remains with the owner. The easement may also serve as an inexpensive interim measure to prevent development on land the municipality may eventually want to purchase." 6 


\section{Public Facilities}

Placement of roads, sewer, water, and other public facilities is an excellent means of influencing development. Placement of public facilities probably has more direct impact on land forms than any other single factor. The success of using public facilities for controlling growth depends on how necessary the facilities are needed.

Environmental Controls

"This set of land development controls has emerged to protect natural processes such as flooding, stormwater runoff, groundeater recharge, or to prevent development in sensative resources such as mountains, slopes, and shorelands, where erosion and other problems could occur with development. Many ordinances identify express uses that are allowed or prevented, or specify exactly where development may occur." 7

Transfer Development Rights

The transfer development rights process permits the transfer of unused development rights of one parcel to another within a defined area in exchange for the payment of a fee as determined by market value. The result of this process is a reduction of development pressures.

Restrictive Covenants and Other Agreements Running With the Land

"This category includes the whole array of deed restrictions, easements, and other negotiated agreements incorporated in land title documents. These are private agreements that 
transfer with ownership. Restrictive covenants are frequently used to tailor the purposes of zoning or other police power restraints to a specific site or to be more restrictive than general public requirements." While the agreements may be incorporated by the developer at the request of a public plat approval agency, the restrictions cannot be amended by public action as can zoning and subdivision regulations." 8

\section{Zoning and Subdivision Techniques}

zoning and subdivision regulations are the primary land use regulations in America today. These devices are at the center of many local efforts to control growth. Among the specific zoning controls that have been utilized to shape growth are:

1) Down zoning: Down zoning refers to a zoning action that reduces the intensity of use of land. This process has often been used in an attempt to reduce or limit future growth.

2) Large lot zoning: This technique involves designating areas for very low density use by requiring development over a very large area.

3) Density zoning: Density zoning has become one of the most popular innovations in zoning in recent years. This technique offers the developer flexibility in designing the site while maintaining the overall density of the site. 
4) Open space zoning: This is a technique developed from a concern about conserving certain open areas. Among the justifications for open space zoning are: hazards to the public health and safety, protect environmentally sensative areas, or mitigate conflicting land use impacts.

5) Development district zoning: The primary aim of development district zoning is to prevent scattered development and sprawl while not discouraging development in general. This can be accomplished by sequencing capital and service improvements in coordination with defined development zones.

Subdivision regulations, in their newer forms, can facilitate sound and orderly municipal growth by controlling the sequence and tempo of development. They also frequentIy require money, land, or improvements to meet the needs generated by larger developments, thus minimizing the impact of development on municipal facilities.

\section{Tax and Fee Systems}

Tax and fee systems are normally set up solely to generate revenues. But because they have such an impact on development, they are increasingly being used as a tool to control growth. Preferential taxation is a popular method of preventing agricultural land from yielding to urban pressures. This law results in a reduction in the assessed valuation of land since assessments are based on the income generating value of the land, rather than its 
best use.

Numerical Restraints or Quota Systems

This approach sets a number rather than an area as a growth limit. Absolute limitations on population growth or housing units are the most controversial growth management methods. "By setting ceilings, they characterize the process as one of no growth rather than of managed or controlled growth and are certain to be challenged in court. Under present legal doctrine it would seem that, to survive litigation, any plan that includes an absolute quota must be reviewed continually with respect to growth patterns within the region and state." 9

Planning Moratoriums and Interim Development Controls

Interim development controls are intended to prevent or restrict further development until the necessary planning has been completed and permanent controls have been developed. "The biggest dilemma in drafting an interim ordinance is deciding which kind of development should be allowed or prohibited during the planning period." ${ }^{10}$ Although a complete moratorium may be desirable, the courts have rarely upheld total prohibitions. Where a partial control is contemplated, existing zoning districts and land-use patterns should be compared with future plans and ordinances to determine what type of development should be allowed during the interim planning period.

A short-term moratorium can also be used to restrict development during an environmentally critical period. These moratoriums are often used when rapid growth has put an 
excess burden on the municipality to provide sewer and water service.

\section{LEGAL CONSIDERATIONS IN GROWTH MANAGEMENT}

One of the crucial concerns in developing growth management policies is whether they are found legal under the state and federal constitutions. A working knowledge of constitutionally mandated duties and challenges for noncompliance with these standards is crucial in the evaluation of growth management policies. Possible constitutional challenges to growth management techniques are briefly summarized below.

\section{Due Process}

The Fourteenth Amendment to the United States Constitution says that no state shall deprive any person of property without due process of law. In general, the due process clause requires that there must be a rational basis for government actions. This clause should be seen only as a limitation on the improper exercise of the police power.

"A growth management policy or regulation could be challenged as having an improper objective, as utilizing means unrelated to an otherwise proper end, or as employing means which, although related to a proper end, are unreasonable to accomplish that end."11 For example, a community that adopts growth management policies which allow only large-lot single family homes in their zoning ordinance, would be subject to challenge on due process since exclu- 
sion on socioeconomic grounds has been held to be an improper objective for the use of police power.

\section{Equal Protection}

The Fourteenth Amendment to the United States Constitution prohibits states from denying any person equal protection of the laws. "The due process clause of the Fifth Amendment extends this guarantee by applying the Fourteenth Amendments equal protection clause to the federal government. "12

At times, growth management programs may have a differential impact on certain citizens of different races even though they may serve a legitimate purpose. To prove a violation of equal protection a racially discriminatory purpose must be proven. Although economic discrimination is not recognized by the Supreme Court, several states, such as New Jersey, prohibit economic discrimination in certain situations.

Right to Travel

The state and federal constitutions do not explicitly guarantee the right to travel, but courts are inclined to recognize the right to travel as a fundamental right and to attribute it to the Constitution. "The right to travel prohibits unreasonable restrictions on interstate migration and settlement and ontrainsient mobility."13 Most growth management tools that restrict migration will probably not violate the right to travel clause it it serves a legitimate public purpose unless it is deemed unreasonable. 
Eminent Domain

The use of eminent domain as a growth control tool has received greater attention recently. As a technique to assist in the control of growth, eminent domain assures government that just because a goal cannot be accomplished through regulation does not mean that it cannot be accomplished at all. It simply means that the landowner will have to be given just compensation for his loss. Generally, eminent domain will encounter few constitutional problems. The only two constitutional limitations on the use of eminent domain are; the taking must be for a public use, and that just compensation must be paid to the owner.

Regional Welfare

The regional welfare challenge is based on the due process requirement that the objective of local government regulatory power is to further the health, safety, morals, or general welfare. In some states this has been extended to include the general welfare not only of the locality, but also of the surrounding region, although most states have not yet recognized a regional welfare standard.

The regional welfare clause in a growth management context might be challenged if a community placed an undue burden on surrounding communities for providing lowerincome housing, accomodating population growth, or providing public facilities. This clause might also be challenged if a locality did not reasonably provide housing for all racial and economic sectors of the population. 
The State Environmental Challenge

There is no language in the Federal Constitution that deals expressly with protection of the environment. It appears that the federal efforts in this regard will be implemented through legislation rather than through constitutional interpretation. Some states, however, have adopted constitutional provisions which declare that the residents of the state have the right to a healthful environment.

From a growth management perspective, interpretations of environmental protection provisions can have a significant effect. "For instance, citizens could challenge their own local government unit for adopting plans that accomodate new population, claiming that the plan was formulated in disregard of the healthful environment to which they are constitutionally entitled. These provisions are also likely to be used as a basis for a defense by local governments to charges of taking, discrimination, exclusionary practices, or failure to provide for the regional welfare."14

\section{CONCLUSION}

There are many factors to consider when developing growth management policies. A community must determine to what extent they want to influence growth, to what extent they can influence growth, local commitment to growth management, growth techniques best suited for fulfilling community objectives, and impacts, as well as potential legal challenges, should be thoroughly considered prior 
to adoption of a growth management plan. In the final analysis, each plan should be looked at in terms of the scope and relevance it has to that specific locality. 


\section{ENVIRONMENTAL SUITABILITY ANALYSIS}

\section{INTRODUCTION}

The technique for determining environmental suitability for this project is expressed in a series of overlay maps that compliment this report. These maps include: surface water and wetlands, topography, land use and vegetation, groundwater, soils, ecological diversity, total constraints, and proposed zoninq. These maps are designed to be used as imputs into the land-use decision-making process for quiding future growth in the Town of Coventry.

The purpose of an environmental suitability analysis is to determine the relative suitability of land forms to support various activities. The principle assumption is that a locations natural environmental characteristics render an area inherently more suitable for some activities than for others. It must be noted however, that development feasibility depends on more than natural features alone. Social and economic considerations, along with the availability of sewers, water, transportation, and other services play a key role in the development of land forms. Environmental vulnerability must be balanced against the needs of the local and regional population, as well as the lands capability and attractiveness to development.

Reasonable consideration of natural resources is, however, essential to the orderly development of Coventry. 
A largely rural community, such as Coventry, is fortunate in still being able to make planning choices based on existing natural resources. Preparing an inventory and classification of natural resources is an integral part of rural environmental planning.

This chapter reviews the principle characteristics of environmentally sensative areas and methods for regulating their development in hopes of increasing public awareness to their importance.

\section{TOPOGRAPHY AND SLOPE}

The development of hillsides must be approached with great caution. "Care must be exercised when tampering with the harmony of slope, soil, vegetation, drainage patterns, and geological foundations." 15 Poorly designed hillside development can result in increases in erosion and runoff, reduce a communities attractiveness, and increase public expenditures.

Erosion

Careless removal of vegetation deprives soils of the stabilizing function it requires from plant roots, causing erosion and a resulting loss of slope. Spring thaws or heavy rains on unstable slopes can produce mass movements, such as landslides. Erosion also causes a reduction of water quality as a result of siltation. 


\section{Runoff}

Hilside development also increases runoff that would ordinarily be retained and transpired by vegetation. Construction of impervious surfaces, such as roads and buildings, decreases the amount of groundwater percolation and thus increases the amount of runoff.

\section{Aesthetics}

A range of hills frequently provides a community with an attractive and distinctive setting. Degradation of hillsides as a result of erosion and loss of vegetation reduces attractiveness and potentially reduces property values.

Cost

Poorly designed hillside developments often result in substantial costs to the public, either for repairs or for protective measures to prevent further damage. Development of hillsides can also be more costly in terms of supplying public utilities and services. Sewer lines, water lines, and roads in hilly areas often require special engineering and specialized equipment, resulting in increased costs.

\section{Guidelines for Hillside Development}

Although there are many factors involved in determining where hillside development is appropriate, it is safe to say that low slopes (under 8 o grade) offer few major obstacles to development. Greater caution should be exercised when building on moderate slopes (8-15\% grade), 
because severe erosion and land slippage may result when the groundcover is disturbed. On extreme slopes (above 15\% grade), development will almost certainly increase runoff causing severe erosion. Since development in these areas is risky, they should be protected whenever possible. One approach to the regulation of hillsides, which has attracted attention recently, are slope-density provisions, which decrease allowable development densities as slope increases. The rationale of the slope-density approach is simple. "Limiting development according to the degree of slope shifts development into areas with the least potential for environmental damage while protecting steeper, more sensative land from development pressures."16

"There are three principal variations of the slopedensity approach: slope-lot lize, slope-natural area, and slope-dwelling units. With slope-lot size, minimum lot size increases with average slope. With slope-natural area, the amount of land to be left in its natural state increases with slope. On the basis of slope-dwelling unit, the number of permissible dwelling units falls as slope increases."17 Either some or all of these variations can be included in a local ordinance. Commonly, however, only one is chosen.

\section{$\underline{\text { SOILS }}$}

Soil properties strongly influence the way man uses land. Soil surveys are being interpreted for many land uses including: agricultural, urbanization, recreation, 
woodland planning and conservation. This project focuses on soil suitability for on-site septic tank systems. Since no public sewer systems currently exist in Coventry, residential development must rely primarily on on-site septic tanks, putting great emphasis on soil suitability for septic tanks.

Wet soils, important because they store water, can be easily contaminated if septic tanks are allowed. Dense soils are also poorly suited for septic tanks. Because they are highly impervious to the free flow of water, septic tanks are likely to overflow and contaminate the water supply. A list of soils found in Rhode Island that are suitable for septic tank filtering fields is summarized in Appendix A.

\section{GROUNDWATER}

Outwash deposits are the most productive aquifers in Rhode Island because of the abundance of well-sorted coarse-grained particles. Such deposits yield water readily to drilled and driven wells. There are two primary areas of glacial outwash in Coventry, the Quinbaug River Area and the South Branch Pawtuxet River Area.

The Quinbaug River is one of the major streams in Connecticut, but the headwaters of several of its tributaries lie in Coventry. The population of this area is very small and groundwater withdrawals are minimal. Ad- . ditional supplies of groundwater can be developed for domestic purposes. However, the possibilities of developing 
large yields from wells in the area are small because of the low permeability of the till deposits.

The South Branch Pawtuxet River Area, in central

Rhode Island, covers about 75 miles. Approximately $50 \%$ of this area is underlain by glacial outwash deposits. The outwash is concentrated in the lowland section of the eastern portion of the area and in the streams emptying into the Flat River Reservoir. Although the total storage capacity of the groundwater reservoir is very large, much of the useable capacity is restricted to the principle part of the reservoir. Well logs indicate that in the 15 square miles of the area beneath and adjacent to Flat River Reservoir and Mishnock Swamp, the water-bearing outwash is more than 50 feet thick. The water table in this area is at or near the surface. The outwash in the other parts of the area, although generally less than 50 feet thick, also contains substantial amount of water.

In addition to providing ample supplies of pure water for many communities, aquifers play an important role in the hydrologic cycle. "Many aquifers occur near lakes and streams with which they are hydrologically interrelated. Many unconsolidated as well as consolidated aquifers depend upon surface water infiltration from lakes and streams for part of their recharge water. Aquifers can also provide important supplementary flow to streams, lakes, and wetlands during dry periods." 18 
Because aquifers are so important as a source of drinking water and as a part of the hydrological cycle, wise planning of development is particularly important over deep aquifers and recharge areas.

\section{VEGETATION AND WILDLIFE}

Too often, vegetation and wildlife are overlooked in the land-use decision-making process. Little thought is given to the delicate relationship among plants, animals, and man. Since uncontrolled development and the subsequent loss of groundcover can often have serious consequences, it is essential that planners understand basic ecological principles.

"As a functional element of the environment, the plant cover serves to stabilize slopes, retard erosion, conserve water quality and quantity, maintain local microclimates, filter the atmosphere, decrease noise, and provide habitat for wildlife. Viewed within this expanded context, vegetation can be utilized not only as a primary determinant in gauging ecological sensativity, but also as an indicator of environmental constraints." 19

\section{WETLANDS}

There has been a radical change in recent years regarding attitudes and policy with respect to wetlands. Although we still have a long way to go in protecting our nations wetlands, we are finally beginning to realize their full value. 
One of the primary reasons for the protection of wetlands lies in their biological productivity. Productivity refers to the total output of living things. Productivity is determined by three elements: 1) the total quantity of living material, 2) the rate of removal of the biomass, and 3) the rate of replacement of the biomass. Well protected, balanced wetland systems continuously produce efficiently and economically and cannot, in undisburbed situations, be depleted.

of all the wetland types, tidal marshes are perhaps the most important in terms of productivity. The richness of this system centers around the accumulation of sediments and the concentration of nutrients within the salt marsh and at the freshwater tidal interface. The food web which supports coastal fisheries begins here. Nearly 908 of the entire annual harvest of fish and shellfish caught by fisherman on the continental shelf of the United States is in large part dependent on the coastal marsh estuarine ecosystem for their survival.

Freshwater wetlands on the other hand, support an equally complex plant and wildlife community. Eastern freshwater and coastal marshes produce some 200,000 ducks annually, and serve as breeding, feeding and nesting areas during migration. Wildlife such as: waterbirds, upland game birds, songbirds, birds of prey, and fur and game mammals, are all dependent on the freshwater ecosystem for their existence. 
Wetlands are also important for their water-holding capacity. Bogs, marshes, organic swamps, and mineral swamps, act as giant sponges which can absorb up to 16 or 18 times their weight in water. In urban areas, this is especially important as the rate and volume of runoff from precipitation is intensified and concentrated by impervious surface areas. Wetlands also provide many recreational opportunities such as fishing, canoeing, birdwatching, and hiking. As educational environments, they furnish natural resources for teaching the dynamics and ecological roles their systems serve.

Protection of Wetlands

The Rhode Island Wetlands Act provides for the protection of all wetlands as defined and gives responsibility for administration of the Act to the Rhode Island Department of Environmental Management. The Act, as amended, provices for a review by DEM for proposed alterations within wetlands or within a zone of 50 feet from and around swamps, marshes, bogs, or ponds; within 100 feet of small streams, and within 200 feet of large streams. The Department has the authority to order restoration and/or bring prosecution with cited penalty for a violation of the Act.

Despite the existence of this Act however, local communities should, at the very least, conduct a detailed inventory of their wetlands. This will help ensure compliance with the State Wetlands Act. A wetlands inventory 
will also define wetland areas of unique ecological value. These areas, in turn, can be given the necessary protection either through standard zoning or subdivision procedures, or through the use of special planning districts designed to encompass the designated wetland areas.

\section{SURFACE WATER}

Maintaining the quality of our water resources is paramount to the general welfare. Water bodies are valuable as a source of water supply, food, recreation, transportation, waste dispersion, power generation, its value to many species of wildlife, and its importance to the hydrologic cycle. If local communities are to protect these valuable resources, they must look beyond individual bodies of water and consider the development of the entire watershed.

\section{Protection of Water Resources}

The present system of water quality management operates primarily through the Department of Environmental Management. Two divisions of DEM, Water Resources and Land Resources, are responsible for controlling pollution from both point and non-point sources. The point sources of pollution result from discharges from industries and municipal sewage treatment plants located in urbanized areas. Nonpoint pollution results from runoff of debris, heavy metals, and other pollutants that accumulate on the large impervious surfaces associated with urban development. 
The major programs administered by DEM that address point sources of pollution are construction grant funding for wastewater treatment facilities, water qualittȳ monitoring, and review of EPA discharge permits. The major nonpoint source programs administered by DEM are the regulation of individual sewage disposal systems and landfills. The Division of Land Resources is responsible for enforcing minimum standards relating to the location, design, construction and maintenance of individual sewage disposal systems. No building permit may be issued by the local community without DEM's approval of the individual disposal system. Despite regulations on the federal and state level to protect water quality, local governments can take various measures to protect their water resources. Land use controls are the principle means used on the local level to regulate nonpoint sources of pollution. The relationship between land use regulations and water quality has been specifically recognized under the Federal Clean Water Act.

Below is a summary of major recommendations to localities for preserving water quality from the Rhode Island State Wide 208 water Quality Plan:

1) Communities should establish a setback requirement of 100 feet from the rainyseason flow line of a stream, or 100 feet from the high-water mark of any lake or pond, wherever possible. A 300 foot setback is recommended from a public supply reservoir, and a 400 foot setback is recommended from 
any groundwater aquifer pumping center.

2) Land disturbance during construction should be minimized, and the natural vegetation should be left intact as much as possible.

3) Large-lot zoning should be considered in rural communities who wish to preserve their rural character and their natural resources.

4) Local communities should zone waterfront areas for large-lot or cluster type developments, in order to reduce runoff.

5) Local governments should use their zoning, subdivision and other controls to minimize water pollution from urban runoff generated at commercial and industrial sites.

6) The maximum density of residential development in public water supply and coastal watersheds and in important aquifer recharge areas should be one dwelling unit for every two acres of land.

7) Communities which rely upon subsurface disposal systems for sewage disposal should voluntarily institute some type of septic tank maintenance program, even if only a minimal effort aimed at providing information to homeowners.

8) As a guideline for future zoning, the following minimum lot sizes are recommended:

- 15,000 square feet in areas that will be served by public water and on-site sewage 
disposal.

- 60,000 square feet in areas that will be served by private wells and on-site sewage disposal.

\section{ECOLOGICAL DIVERSITY}

Areas of high ecological diversity should be planned for accordingly. Low-density, or open space zoning, clustering, overlay districts, or various performance standards should be used in these areas. A review of the inventory process used in the mapping of ecologically diverse areas in Coventry, which compliment this report, can be found in Appendix B.

\section{CONCLUSION}

Planning based on natural resources results not only in a more pleasing environment, but it can also save money. The direct costs of not protecting environmentally sensative areas can be high. Costs may include: the reduction of property values, finding alternative water sources, installing expensive stormwater sewers, or the potential costs created by a flood or landslide. Using a natural resources inventory in conjunction with the traditional inventory of existing land uses provides a firm basis for sensable locational decisions. 


\section{GROWTH MANAGEMENT AND COVENTRY}

As we have seen in Chapter I, there are many techniques available for managing growth at the local level. While it may appear that decision-makers can simply pick and choose from among the various techniques available, growth management plans must be looked at in terms of the scope and relevance it has to that specific locality.

Coventry is a town that has been slow to implement regulatory controls and planning techniques. This is often a common occurence in rural areas. Many residents see land-use controls as an infringement on their personal liberties. This seems to be a prevalent attitude in the more rural areas of coventry. Also, land-use controls are simply not needed in some extensively rural communities. While this might have been the case in Coventry 30 years ago, it is no longer the case today. Coventry is a rapidly growing town of nearly 30,000 residents in serious need of confronting the issue of future growth.

In developing policies that confront the issue of growth, this report recognizes the various limitations, within the planning context, that currently exist in Coventry. The town currently employs only one full-time planner, has an outdated Comprehensive Plan, and must cope with the fact that we are living in a period of fiscal austerity. Keeping these factors in mind, it would be foolish to recommend any techniques that would be overly 
costly, such as land acquisition, unless it was absolutely necessary for the best interest of the town. That is not to say that land acquisition is inappropriate for Coventry in certain situations, but that on a largescale basis it is unsuitable because of the cost. Also, any techniques that would be unduly burdensome to carry out, would be inappropriate at this time, since there is only one planner for the town.

Clearly, the most effective means available to Coventry for effectively dealing with future growth is through the diligent and faithful enforcement and use of the town's zoning and subdivision ordinances. Both traditional and innovative zoning and subdivision techniques (preferably both) can be an extremely effective method of controlling growth if they are properly administered and enforced. An effective zoning and subdivision ordinance can facilitate sound and orderly growth by controlling the sequence and tempo of development.

Below is an analysis of Coventry's zoning and subdivision ordinances as they pertain to future growth, as well as a series of recommendations.

\section{ZONING}

The last amendment to Coventry's zoning ordinance was in 1974. Table II below, summarizes the zoning districts (mapped) in the town. 
Table II

Zoning Classifications

\begin{tabular}{lcccc} 
Zone & Use & $\begin{array}{c}\text { Minimum } \\
\text { lot size } \\
\text { (sq. feet) }\end{array}$ & $\begin{array}{c}\text { Minimum } \\
\text { frontage } \\
\text { (feet) }\end{array}$ & $\begin{array}{c}\text { Minimum } \\
\text { depth } \\
\text { (feet) }\end{array}$ \\
\hline RR & Rural Residential & 87,000 & 45 & 90 \\
R-20 & Residential & 20,000 & 35 & 40 \\
R-10 & Residential & 10,000 & 25 & 30 \\
NB & Neighborhood Bus. & ----- & 20 & 25 \\
GB & General Business & $-\ldots--$ & 30 & 40 \\
I & Industrial & ----- & 50 & 50
\end{tabular}

Rural Residential RR District

This district covers a large portion of central and western parts of town into which urban type development should logically expand as the need occurs.

Residential R-20 District

This district is composed of certain quiet low density residential areas of the town, plus certain open areas where similar residential development will likely occur in the future.

Residential R-10

This district is composed of certain medium density residential areas and smaller undeveloped areas where similar development appears desirable.

Neighborhood Business NB District

This district is composed of certain land and structure to provide for the retailing of co-modities classed by merchants as "Convenience Goods" such as groceries, milk, 
and drugs, and the furnishing of certain personal services. General Business GB District

This district is composed of certain land and structures to provide for the retailing of commodities and the furnishing of services which depend primarily on vehicular traffic.

Industrial I District

This district is composed of certain land and structures so situated as to be suitable for industrial development.

Coventry's zoning ordinance also has the provisions for the establishment of; a Planned Residential District (PRD), a Planned Commercial District (PCD), a Planned Unit Development (PUD), and a Single-Family Cluster Development District. The PRD and PCD Districts are intended to be used as overlay zones. These zones may be created by combining specific districts with others. The PUD and cluster provisions were developed to promote the conservation of open space, natural resources and ecological features, and to prevent sprawl and wasteful land development practices.

It is evident that Coventry's current zoning ordinance does not allow sufficient flexibility to effectively plan for future growth. Greater flexibility is needed in accommodating residential development, especially in rural areas. Currently, virtually all of central and western Coventry is zoned RR-Rural Residential (2 acres per dwelling unit). This 
is a loosely regulated district that will generally allow any form of reasonable development.

In order to protect the most valuable natural areas in Coventry, rural areas should be zoned to encourage growth to areas that will accomodate it, while environmentally sensative areas should have a lower density zone $(5$ acres per dwelling unit) in order to discourage development and minimize impacts from development. Also, zoning should be utilized to allow cluster developments in undeveloped areas. This can be accomplished by allowing bonus incentives to developers for attempting a cluster development.

In past years, the regulation of zoning has been treated very loosely in Coventry. While revision of the zoning ordinance is necessary, it will prove fruitless unless a tightening of the regulatory process is adhered to. The best written zoning ordinance is of little value if the use of special permits and variances are allowed to be used liberally.

In order to improve the town's zoning ordinance to effectively plan for future growth the following recommendations have been developed.

1) A 5 acre zoning district ( 5 acres per dwelling unit) should be developed. As growth pressures continue, this district would allow the town the opportunity to maintain low density developments in specified areas such as; valuable agricultural lands, environmentally sensative 
areas, or areas of town where public utilities are deficient. This district would be used primarily in the extreme western portions of the town.

2) An R-30 zoning district (3/4 acres per dwelling unit) should be developed. This district would be used in central portions of town that are best suited for future development. Developing a district of this size would offer the town much greater flexibility in planning for future residential development.

3) An Open Space District should be developed. This district would be used in areas of unique recreational, environmental, or historical value, by protecting it from future development.

4) The cluster and PUD amendments should be rewritten to provide greater incentives to developers. Future development in central and western Coventry should be clustered wherever possible, rather than be allowed to occur in a sprawled, inefficient manner. While a cluster and PUD provision currently exist in Goventry, the town is reluctant to allow this form of development. Only one cluster development has been built in Coventry to date. This is an invaluable tool to a rapidly growing community such as Coventry and should be taken advantage of. One form of incentive is to allow builders to use a higher density than is currently allowed in zoning district. 
This report recommends that builders be allowed to build one dwelling unit on 20,000 square feet rather than 30,000 in the proposed R-30 district, if they use a cluster rather than a traditional subdivision. Also, in areas that would be zoned in the proposed 5 acre district, builders should be allowed to build one dwelling unit per acre if they use a cluster form development. This would almost guarantee that any substantial development in this district would have to be clustered, thus reducing the possibility of wasteful, sprawl development.

5) Greater emphasis should be taken to use zoning within the context of natural systems. An evaluation and inventory of environmentally sensative areas should be included in the land-use decision-making process.

6) A zoning ordinance based on the Comprehensive Plan is the single, most important means of translating the Plan's proposals into action. The basic relationship between these two elements cannot be overstressed, for one is dependent upon the other. Since the Coventry Comprehensive Plan was originally written in 1966 and updated in 1973 (the update focused primarily on updating data rather than community goals and objectives), it is essential that it be updated and the zoning ordinace revised to accommodate the updated plan.

7) A proposed zoning map for Coventry has been developed and proceeds this report along with a 
series of other maps that analize environmental suitability.

\section{SUBDIVISION}

In rural areas such as Coventry, subdivision regulations are easily as important as zoning, and often more important. With approximately $80 \%$ of Coventry presently undeveloped, and growth pressures increasing, environmental considerations are essential to a well written subdivision ordinance. As can be seen from Table III, there are a great many environmental shortcomings in the Coventry subdivision regulations. The ordinance does not protect for the removal of vegetation, little concern with topographic features, soils, drainage, and runoff, and no protection for wetlands and water bodies beyond state regulations. Another glaring shortcoming in the Coventry regulations are that there are no measures taken for the protection of water supply. This is a particularly severe shortcoming, since much of the town relies on wells as a source of water supply. The following recommendations have been developed for the improvement of environmental considerations in the Coventry subdivision ordinance.

1) Develop an erosion and runoff ordinance. This ordinance will provide measures to preserve and protect the natural environment, regulating the alteration of land and topography, removal of vegetation and trees, set standards for drainage, 
ENVIRONMENTAL SUBDIVISION REGULATIONS - COVENTRY

Factor

Considered Not and/or Reguired Considered

VEGETATION AND TREES

-Minimize Cutting of Vegetation

$\mathrm{X}$

-Trees may be Required to be

Planted

$\mathrm{X}$

-Buffer Screens Required Between

Conflicting Uses

-Trees to be preserved in

street R.O.W.

-Design Criteria Specified

$\mathrm{X}$

-Construction Specifications provided

-Location of Large Trees to be Indicated on Plat Maps

NATURAL FEATURES

-Natural Features to be

Preserved

- Layout of Subdivision in Accordance with Natural Features

- Natural Features Preserved in

Land Dedicated to the Town

$\mathrm{X}$

LAND SUITABILITY

-Planning Body Rules on Suitability of Land

$\mathrm{X}$

- Compatability of Subdivision with

Surrounding Development

$\mathrm{X}$

WETLANDS AND WATER COURSES

-Alteration of Wetlands Forbidden

$\mathrm{X}$

$\mathrm{X}$

-Buffer Zone Around Wetlands

$\mathrm{X}$

-Water Courses Protected by

Desilting Basins

-Ground and Surface Water Pollution Forbidden

-Proposed Changes to Water Courses Require Additional Plat Infomation be Submitted

-Impact of Subdivision on Ground and Surface Water

WATER SUPPLY

-Proof of Adequate Water Supply Required 
ENVIRONMENTAL SUBDIVISION REGULATIONS - COVENTRY

Factor

Considered

Not

and/or Reguired Considered

WATER SUPPLY (CONTINUED)

-Buffer Zone Around Wells

-Water Supply Safeguarded from

Flood Waters

-Effect of Subdivision on

Water Supply

$\mathrm{X}$

$\mathrm{X}$

$\mathrm{x}$

EROSION AND SEDIMENTATION (E\&S)

-E\&S Plan Required

-Design Standards for E\&S Control

-Performance Principles for E\&S Control

-Minimize Cutting of Vegetation

-Watercourses Protected by Disilting Basins

-Soil Erosion to be Minimized

-Impact of Subdivision on E\&S

DRAINAGE

-Drainage Plan Required

- Drainage Structures Required

- Natural Waterways to be Maintained for Drainage

-Land Subject to Flooding must Conform to Grade Standards

-Impact of Subdivision on Surface Drainage

-Natural Contours not to be Altered to Reduce Natural Drainage Capability of Land

- Design Standards for Drainage

-Construction Specifications for Drainage

$\mathrm{x}$

$\mathrm{x}$

$\mathrm{X}$

$x$

$x$

$\mathrm{X}$

$x$

$\mathrm{x}$

$\mathrm{x}$

$\mathrm{x}$

$\mathrm{X}$

$x$

$\mathrm{X}$

$\mathrm{X}$

SOILS AND GEOLOGY

-Soils Suitability Tests Required

-Soils Based Design Criteria for Sewage Disposal Units

-Minimum Lot Dimensions Subject to Suitability of Soils and Geology

-Topsoil not to be Removed without

Planning Board Approval

-Soils Survey Report Required

-Soil Culture Required

$\mathrm{x}$

$\mathrm{x}$

$\mathrm{X}$

$\mathrm{x}$

$\mathrm{x}$

$\mathrm{x}$

SEWAGE DISPOSAL

-Soil Suitability Tests Required

-Design Criteria for Individual

Sewage Disposal Systems 
SEWAGE DISPOSAL (CONTINUED)

-Minimum Lot Dimensions Subject

to Change Based on Safe and

Adequate Operation of Sewage

Disposal System

-Sewage Disposal System not to

Impact Water Supply, Groundwater,

or Wetlands

-Buffer Zone Around Wetlands

-Buffer Zone Around Wells

$x$

$\mathrm{X}$

$\mathrm{X}$

TOPOGRAPHY

-Grades for Streets and Lots

to Follow Natural Contours

-Maximum Slope Ratios Specified

$\mathrm{X}$

for slopes without Retaining

Structures

- Natural Contours not be be

Altered to Reduce Natural

Drainage

-Slope may Determine Minimum

Lot Size Requirements

$\mathrm{X}$

SOLID WASTE DISPOSAL

-Debris from Clearing Land to

be Properly Disposed of

-Impact of Subdivision on Solid Waste

$\mathrm{X}$

$\mathrm{X}$

AIR POLLUTION

-Dust Control Measures

Required During Grading X

TRANSPORTATION

-Impact of Subdivision on Vehicular

Traffic and Public safety

$\mathrm{X}$

LANDSCAPING AND AESTHETICS

-Land Dedicated to the Town to

Suitable for Public Purposes

-Site Plans Required

$\mathrm{X}$

$\mathrm{X}$

-Land Dedicated to the Town

to be Graded and Landscaped

- Layout and Design to be in

Accord with Natural Features

-Gridiron Street Pattern to be

Avoided

$\mathrm{X}$

$\mathrm{X}$

$\mathrm{X}$

$\mathrm{X}$

1 Soil suitability tests (percolation tests) required from DEM as to suitability of soil to safety support individual on-site disposal units. 
FOOTNOTE CONTINUED:

Source: Coventry Town Planner Thomas Deller 4/81.

Note: The model used for this analysis was taken from Fiscal and Environmental Impacts of Subdivision Regulations in Rhode Island by Riad G. Mahayni and Margurite Reich. 
and require erosion and sedimentation controls. This ordinance would require the location of existing stands of trees and measure to preserve them, plans for grading, and analysis of runoff under existing conditions and under proposed construction.

2) Regulations should be developed to include a prohibition of soil removal, the submission of a soil type map, the requirement that no structures shall be constructed on soils classified as unsuitable, and to encourage cluster development to allow developers to avoid construction on unsuitable soils.

3) Regulations should be developed to provide for a buffer zone around streams and wetlands. This provision should also require the developer to provide information on the impacts of the development on ground and surface water, as well as wetlands.

4) Provisions should be made to guarantee the protection of water supplies from sewer systems. As no public sewer systems currently exist in Coventry, the contamination from sewers is a real concern that should be addressed.

\section{CONCLUSION}

It is evident that the town's zoning and subdivision ordinances are in serious need of revision if they are to 
effectively control future growth. These revisions should occur in conjunction with an updated comprehensive plan. More emphasis and flexibility is needed in regulating land uses with regards to environmentally sensative areas. Coventry is fortunate to still be able to make planning decisions around natural systems, hopefully they will take greater advantage of this opportunity through the use of their zoning and subdivision ordinances. Finally, revision of the zoning and subdivision ordinances alone, will not guarantee harmonious growth unless the regulatory process is adhered to more strictly in the future. 


\section{CONCLUSION}

It is hoped that this report has been informative in clarifying the issue of growth in Coventry. Although a series of maps and recommendations have been developed to assist Coventry in formulating growth policies, the real key to successfully planning for future growth is an informed and involved public. Citizen participation in the land-use decision-makind process is absolutely essential since, ultimately, these decisions will effect every member of the community. It is the responsibility of town officials to focus attention on the issue of growth and the need for reshaping current land-use policies.

As was pointed out in the previous chapter, the effective use of zoning and subdivision techniques, along with reasonable consideration for environmentally sensative areas, is currently the best method available for controlling future growth. As Coventry continues to experience growth in the coming decades, more elaborate growth control techniques may be required to limit growth. That is why it is so important to keep an updated Comprehensive Plan that analizes current issues and needs of the town and plans for them accordingly. Only when local officials and residents acknowledge the need for more regulatory controls and planning expertise will the impact from future growth be minimized. 


\section{FOOTNOTES}

1. Randall Scott et al., Management and Control of Growth, Volume III, p. 340 .

2. IBID., p. 334 .

3. David R. Godschalk et al., Constitutional Issues of Growth Management, p. 174 .

4. IBID., p. 178 .

5. Robert C. Einsweiler et al., Urban Growth Management Systems, p. 35.

6. The Citizens Advisory Committee on Environmental Quality et al., Community Action for Environmental Quality, p. 16 .

7. Robert C. Einsweiler et al., Urban Growth Management Systems, p. 37.

8. IBID., p. 39.

9. IBID., p. 45 .

10. IBID., p. 46

11. David R. Godschalk et al., Constitutional Issues of Growth Management, p. 44 .

12. IBID., p. 168.

13. IBID., p. 169 .

14. IBID., p. 107.

15. IBID., p. 107.

16. Robert C. Einsweiler et al., Urban Growth Management Systems, p. 73.

17. IBID., p. 74.

18. IBID., p. 28 .

19. William M. Marsh, Environmental Analysis for Land Use and Site Planning, p. 110.. 
$\underline{\text { APPENDIX A }}$

RHODE ISLAND SOILS SUITABLE FOR ON-SITE SEWAGE DISPOSAL

Map Symbol and Soil Name

$13 \mathrm{~A}$

Dutchess silt loam,

$0-3 \%$ slope

$13 \mathrm{~B}$

Dutchess silt loam,

3-88 slope

$13 \mathrm{C}$

Dutchess silt loam,

8-15\% slope

$13 \mathrm{XB}$

Dutchess very stony silt

loam, 3-8\% slope

$13 \mathrm{XC}$

Dutchess very stony silt

loam, 8-15\% slope

$14 \mathrm{~A}$

Gloucester sandy loam,

$0-3 \%$

$14 \mathrm{~B}$

Gloucester sandy loam,

3-8\% slope

$14 \mathrm{C}$

Gloucester sandy loam,

8-15\% slope

$14 \mathrm{XB}$

Gloucester very stony sandy loam,

3-8\% slope

$14 \times C$

Gloucester very stony

sandy loam, 8-15\% slope

$15 \times C$

Gloucester-Hinckley

very stony loamy sands,

3-15: slope

$16 \mathrm{~A}$

Bridgehampton silt loam, 0-38 slope
Limitations for on-Site

Sewage Disposal

Slight

Slight

Moderate; slope

Moderate; stoniness

Moderate; slope, stoniness

Slight

Slight

Moderate; stoniness

Moderate; stoniness

Moderate; slope, stoniness

Moderate; slope, stoniness

Moderate; permeability 
Map Symbol and Soil Name

$16 \mathrm{~B}$

Bridgehampton silt loam, 3-8\% slope

$16 \mathrm{C}$

Bridgehampton silt loam, 8-15\% slope

$17 \mathrm{~A}$

Merrimac sandy loam, $3-8 \%$

17B

Merrimac sandy loam, 3-8\% slope

$18 \mathrm{~A}$

Warwick sandy loam,

3-8\% slope

18B

Warwick sandy loam, $3-8 \%$

\section{$24 \mathrm{~A}$}

Narragansett silt loam, 0-3 slope

\section{$24 \mathrm{~B}$}

Narragansett silt loam, 3-8요 slope

$24 \mathrm{C}$

Narragansett silt loam, 8-15\% slope

$24 \times A$

Narragansett very stony

silt loam, 0-3의 slope

$24 \mathrm{XB}$

Narragansett very stony

silt loam, 3-8\% slope

27A

Hinckley gravelly sandy

loam, 0-3q slope

27C

Hinckley gravelly sandy loam, 3-15\% slope
Limitations for On-Site Sewage Disposal

Moderate; permeability

Moderate; permeability, slope

slight

slight

Slight

slight

slight

slight

Moderate; slopes

Moderate; stoniness

Moderate; stoniness

Slight

Moderate; slopes 
Map Symbol and Soil Name

$28 \mathrm{C}$

Hinckley-Enfield complex, $0-15 \%$ slope

$40 A$

Canton and Charlton fine sandy loams, 0-3\%

$40 B$

Canton and Charlton fine sandy loams, 3-8\%

$40 \times B$

Canton and Charlton fine sandy loams, 3-8\% slope

$40 \times C$

Canton and Charlton very stony fine sandy loams, 8-15\% slope

49A

Bridgehampton silt loam, till substratum,

0-3\% slope

\section{$49 B$}

Bridgehampton silt loam, till substratum,

3-8\% slope

$49 \mathrm{C}$

Bridgehampton silt loam, till substratum,

8-15\% slope

49XA

Bridgehampton very stony

silt loam, till substratum, 0-3항 slope

$49 \times B$

Bridgehampton very stony

silt loam, till substratum, 3-8용 slope

$49 \times C$

Bridgehampton very stony

silt loam, till substratum, 8-15\% slope
Iimitations for on-Site Sewage Disposal

Moderate; slopes

Slight

Slight

Moderate; stoniness

Moderate; slopes, stoniness

Moderate; permeability

Moderate; permeability

Moderate; slopes, permeability

Moderate; permeability, stoniness

Moderate; permeability, stoniness

Moderate; permeability, stoniness 
Map Symbol and Soil Name

$50 A B C$

Enfield silt loam

0-15\% slope

$51 \mathrm{AB}$

Windsor loamy sand

0-8\% slope

62A

Quonset gravelly sandy

loam, 0-3\% slope

$62 \mathrm{C}$

Quonset gravelly sandy

loam, 3-15\% slope
Iimitations for on-site

Sewage Disposal

slight

Slight

Slight

Moderate; slopes 


\section{APPENDIX B}

Below is a summary of the point rating system used in the mapping of ecologically diverse areas in Coventry. This rating has been devised by Dr. John Kupa, Professor, in Community Planning and Area Development, University of Rhode Island.

Grid map into 2 inch squares and total the points for each square.

Open Water-Area

A. $20 \%$ cover

B. 10-198

C. $-10 \%$

Streams-Total Length

A. 2000 feet

B. 1000-2000 feet 2

C. -1000 feet Order of Stream (Cumulative)

A. $3 r d-4$ th order streams 3

B. 1st-2nd order streams 2

C. 1st order stream 1

Wetlands - Total Length
A. 2000 feet
B. 1000-2000 feet
C. -1000 feet

.


Wetlands - Area

A. 338 cover

B. 10-33\%

C. $-10 \%$

Wetlands - Classification
Points

3

2

1

A. Highest

3

B. Moderate

2

C. Lowest

1

Vegetation-Types
A. 6
3
B. 3-5
2
C. 1-2
1

Wildlife Habitat
A. Forest $25 \%$ or more
1
B. Farm 258
2
C. Wetlands $25 \%$
2
D. Surface Water $25 \%$
2

Total Points
A. High Diversity
$14+$
B. Moderate Diversity
$7-13$
C. Low Diversity
$1-6$ 


\section{BIBLIOGRAPHY}

1. Brower, David J. et al. Urban Growth Management Through Development Timing. New York: Praeger Publishers, 1976.

2. Burrows, Lawrence B., Growth Management: Issues, Techniques, and Policy Implications. Rutgers University: Center for Urban Policy Research, 1978.

3. Chapin, F. Stuart and Edward J. Kaiser. Urban Land Use Planning. Chicago: University of Illinois Press, 1979.

4. Community Planning and Area Development, Cooperative Extension Service, University of Rhode Island. Preserving Open Space: Approaches for Rhode Island Communities; Land Management Acquisition Taxation, 1978 .

5. Doherty, Joanna, Michael Everett and Cecilia Searle. A Rural Land Use Primer for Rhode Island. University of Rhode Island, Agricultural Experiment station, 1976.

6. Downs, Anthony. The Costs of Sprawl. Washington, D.C.: The Real Estate Research Corporation, 1974.

7. Einsweiler, Robert C. et al. Urban Growth Management Systems. Chicago: Planning Advisoty Service, 1976.

8. Erley, Duncan, Charles Thurow, and William Toner. Performance Controls for Sensitive Lands. Chicago: Chicago: Planning Advisoty Service, 1975.

9. Falk, David and Herbert M. Franklin. Local Growth Management Policy: A Legal Primer. Washington, D.C.: The Potomac Institute, 1975.

10. Finkler, Earl and David L. Peterson. Nongrowth Planning Strategies: The Developing Power of Towns, Cities, and Regions. New York: Praeger Publishers, 1974.

11. Getzels, Judith and Charles Thurow. Rural and Small Town Planning. Chicago: American Planning Association, 1979.

12. Godschalk, David R. et al. Constitutional Issues of Growth Management. Chicago: The ASPO Press, 1977.

13. Godschalk, David R., Norman Axler and Devon M. Schneider. The Carrying Capacity Concept As A Planning Tool.

Chicago: Planning Advisoty Service, 1978.

14. Hendler, Bruce. Caring for the Land. Chicago: The ASPO Press, 1977. 
15. Kattman, Rick et al. Wetlands Inventory, City of East Providence. Landscape Analysis and Natural Design, 1974 .

16. Kupa, John J. and William R. Whitman. Land-Cover Types of Rhode Island: An Ecological Inventory. University of Rhode Island: Agricultural Experiment Station, Bulletin 409,1972 .

17. Levye, Marc C. and Marc Rousseau. Residential Growth Control Plan for North Kingstown. University of Rhode Island: Department of Community Planning and Area Development, Thesis Project, 1978.

18. MacConnell, William P., Remote Sensing Land Use and Vegetative Cover in Rhode Island. University of Rhode Island: Cooperative Extension Service, 1974.

19. Mahayni, Riad G. and Margurite Reich. Fiscal and Environmental Impacts of Subdivision Regulations in Rhode Island. University of Rhode Island: Agricultural Experiment Station, 1979.

20. Mancuso, Michael L. Farmland Preservation in Massachusetts and Rhode Island. University of Rhode Island: Department of Community Planning and Area Development, Thesis Project, 1980.

21. Marsh, William M. Environmental Analysis for Land Use and Site Planning. McGraw-Hill Co. 1978.

22. McHarg, Ian L. Design With Nature. New York: Doubleday and Company, Inc., 1971.

23. Meshenberg, Michael J. Environmental Planning: Environmental Information for Policy Formulation. Chicaqo: Planning Advisory Service, 1970.

24. National Wetlands Technical Council. National Symposium on Wetlands. Florida, 1978.

25. New England Rivers Basin's Commission. How to Guide Growth in Southeastern New England. $197 \overline{5}$

26. Noble, Jack. A Proposed System For Regulating Land Use in Urbanizing Counties. Chicago: The ASPO Press.

27. Rhode Island Department of Community Affairs. Comprehensive Community Plan, Coventry, Rhode Island, 1973.

28. Rhode Island Development Council. Geological Bulletin No. 11, Appraisal of the Ground-Water Reservoir Areas in Rhode Island. 
29. Rhode Island Development Council. Rhode Island City and Town Monographs - Coventry, Rhode Island, 1979.

30. Rhode Island Development Council. Town of Coventry, Rhode Island. Comprehensive Community Plan 1966.

31. Rhode Island Statewide Planning Program. Rhode Island Population Projections By County, City, and Town. April 1979.

32. Rhode Island Statewide Planning Program. 208 Water Quality Management Plan for Rhode Island, 1979.

33. Rubenstein, Harvey M. A Guide to Site and Environmental Planning. New York: John Wiley and Sons Inc., 1969.

34. Sargent, Frederic 0. Rural Environmental Planning. Burlington: University of Vermont, 1976.

35. Scott, Randall, David J. Brower, and Dallas D. Miner. Management and Control of Growth, Volumes I-IV. Washington, D.C.: The Urban Land Institute, 1975.

36. Society for the Protection of New Hampshire Forests. Guiding Growth: A Handbook for New Hampshire Townspeople. Concord.

37. State of Connecticut Department of Environmental Protection. Developers Handbook. Hartford.

38. The Institute of Rational Design Inc. Design and Control of Land Development in Suburban Communities.

39. Town of Coventry. Subdivision Ordinance, 1979.

40. Town of Coventry. Zoning ordinance, 1974.

41. Unger, David G. et al. Soils and Land Use Planning. Philadelphia, The ASPO Press, 1966. 